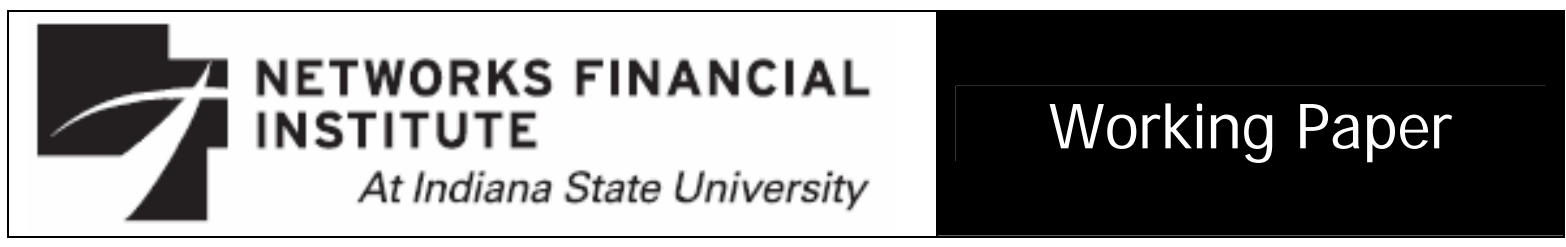

2006-WP-13

November 2006

Depositor Discipline and Bank Risk-Taking Behavior: Evidence From the South-East Asian Financial Crises

\author{
M. Kabir Hassan and M. Ershad Hussain
}

\begin{abstract}
This paper examines whether the risk-taking behavior of commercial banks in five countries of South-East Asia changed after the Asian Crises of 1997. The paper utilizes the framework created by Gruben et al (1997, 1998, and 2003). It also examines the connection between the risk-taking behavior and depositor discipline of these banks after the Asian Crises of 1997. Based on bank level data from the Bank Scope, 2005 CD, the paper presents evidence that the state of depositor discipline is very weak in the selected countries even after the Asian Crises. Evidence also shows that the risk taking behavior of commercial banks did not change much before and after the Asian Crises of 1997, and that perfect competition prevailed both before and after the Crises in the banking sector. Finally, evidence also shows that the there is no connection between risk-taking behavior and depositor discipline.
\end{abstract}

\title{
About the Authors:
}

Dr. Kabir Hassan is a tenured professor at the University of New Orleans and also holds a visiting research professorship at Drexel University, Philadelphia. He is a financial economist with consulting, research and teaching experiences in development finance, money and capital markets, corporate finance, investments, monetary economics, macroeconomics and international trade and finance. He has published five books, over 70 articles in refereed academic journals and has presented over 100 research papers at professional conferences globally.

M. Ershad Hussain is a Ph.D. candidate in Financial Economics at the University of New Orleans. He presented papers in the FMA and SWFA.

Keywords: Depositor discipline, commercial banks

The views expressed are those of the individual author and do not necessarily reflect official positions of Networks Financial Institute. Please address questions regarding content to M. Kabir Hassan at Kabir_Hassan@comcast.net. Any errors or omissions are the responsibility of the author.

NFI working papers and other publications are available on NFI's website (www.networksfinancialinstitute.org). Click "Research" and then "Publications/Papers." 


\section{Depositor Discipline and Bank Risk-Taking Behavior: Evidence From the South-East Asian Financial Crises}

\section{Kabir Hassan and M. Ershad Hussain}

\section{Introduction}

In the wake of successful regulatory changes in the developed countries ${ }^{1}$, many developing countries started to liberalize their financial sectors in the 1990s. One of the major elements of such liberalization was the reform of the financial sector $^{2}$ with the twin objectives of increasing efficiency of the commercial banks and ensuring the soundness of the financial sector where commercial banks, public or private, play a major role. It was believed that such improvement in the banking sector would foster economic growth via efficient allocation of scarce capital, both domestic and foreign in the host countries.

In spite of its success the liberalization policies now face a backlash in several developing countries. Critics present the cases of international financial Crises (Mexican Crises in 1995 and Asian Crises of 1997) and domestic Crises (Japan in late 1990s, Turkey during early 2000s) in support of their views. The argument is about the timing, pace and the ways such policies were implemented. These have renewed the profession's interest on the issues of 'competition and stability' in the banking sector.

\footnotetext{
${ }^{1}$ In the European Union the major regulations that opened up ways for changes in the banking sector is the Second Banking Coordination Directive of European Union allowing the Single Banking License in 1991. For 10 OECD countries, the Basel I Accord of 1988 initiated a change towards stricter capital requirements for parts of banks. In the USA, several regulations were implemented during the 1990s starting with the Basel I Accord, followed by the FDIC Improvement Act (FDICIA) of 1991 (emphasis on adequate capitalization of banks and allowing special privileges, or eligible operations, for banks deemed to be well-capitalized), Riegle-Neal Act of 1994 (allowed interstate banking), and the Financial Sector Modernization Act of 1999 (allowed banks to enter insurance, real estate and security related activities).

${ }^{2}$ Often such financial sector reforms were implemented as part of larger packages of program, popularly known as SAP (Structural Adjustment Policies) sponsored by multinational development agencies, namely the World Bank and the International Monetary Fund. Major elements of such financial sector reform package included but were not limited to the following: i) interest rate liberalization; ii) allowing entry of foreign banks; iii) privatization of government owned banks; and iv) abolishing government directed credit to preferred sectors etc. In short, the main objective of such reform programs was to put an end to financial repression.
} 
One consequence of liberalization and privatization of the banking sector in the developing countries was that it increased competition in the banking sector of the host countries as documented by IMF, 1998 and several other studies ${ }^{3}$. Studies on the effect of competition on the financial sector, especially banks, have attracted wide-spread attention in recent years. Most of these studies deal with the impact of competition in banking sector on i) economic growth; ii) performance of banks; iii) efficiency change of banks; iv) adoption of modern technology by banks; v) stability of commercial banks; vi) the access of firms and households to financial services and external financing; vii) cost of financial intermediation ${ }^{4}$; and vii) changes in the risktaking behavior of banks. In the present paper we focus on the last topic by studying two of the major factors of risk- taking behavior: depositor discipline and degree of competition.

Until recently, most of the literature in this field has concentrated on the determinants of financial or bank Crises (viz. Calomiris, 1990; de la Caudra and Valdes, 1992; Kaminksy and Rienhart, 1996; McKinnon and Pill, 1996; DemirgucKunt and Detragiache, 1998, 2005), where incentives that lead banks to take on more risk took a back stage. However, our approach to studying the problem studies the changes in risk incentive directly and is relatively new. Following Gruben et al. (1997, 1998, and 2003) we examine the shifts in bank risk and factors that make such activity more attractive directly.

Gruben et al (1999) pointed out that two major factors that cause banking panic are: lack of market (depositor) discipline and financial liberalization. Demirguc-Kunt (19981, 1998b, 2005) and Kaminsky and Reinhart (1996) found evidence indicating that risk-taking activities of banks increase in the wake of liberalization, especially in countries where financial institutions are underdeveloped, law enforcement is weak and regulatory supervision is inadequate,

\footnotetext{
${ }^{3}$ Klaus et al (1997)

${ }^{4}$ Demirguc-Kunt et al ( 2005)
} 
which is more likely in the developing countries. In developing countries, such liberalization often results in increased opportunities for excessive risk-taking and fraud.

Demirguc-Kunt (1998a, 1998b, and 2000a) found evidence that risk-taking activities of banks also increase due to the moral hazard problem created by deposit insurance. This shows that explicit deposit insurance reduces depositor discipline, which increases moral hazard. Thus two factors directly related to stability of banks are market discipline and financial liberalization.

Apart from the recent increase in bank crises and the resultant academic interest, in June, $2004^{5}$ the Basel Committee and the OECD countries finalized Basel II. It is expected that before long this will become the internationally accepted standard of bank supervision and regulation, just like its predecessor Basel I, which is at different phases of implementation in over 100 countries around the world. The primary focus of Basel II is risk measurement and risk management ${ }^{6}$, making the changes in risk behavior of banks in response to policy changes more important than before. At the same time, the Committee also decided that "market discipline" be made one of the three pillars, on which future financial regulation should be based, because such discipline imposes strong incentives for banks to conduct their business in a safe, sound, and efficient manner and also to hold adequate capital ${ }^{7}$. All this is expected to reduce the risk of a bank portfolio ${ }^{8}$. However, as pointed out, there is little empirical evidence on this issue, and hence this paper makes an attempt to cover that gap.

Despite strong interest and rapid progress in research on some issues, research on developing and emerging market countries remain incomplete, with the

\footnotetext{
${ }^{5}$ Web-site of Basel Committee on Bank Supervision.

${ }^{6}$ Inaugural address by Nicholas, C Pan, Superintendent, Office of the Superintendent of Financial Institutions, Canada, Chairman of the Basel Accord Implementation Group, February, 2005.

${ }^{7}$ According to the June, 2004 declarations of Basel II Accord, the three pillars include (i) riskweighted capital ratios; (ii) supervisory oversight; and (iii) market discipline.

${ }^{8}$ Ghosh, Saibal and Abhiman Das, Econ-Papers, 2004.
} 
exception of studies of some countries during and following Crises, including of Argentina(1995), Canada(1984-86), Mexico(1995), Singapore(1997-99), Norway(1987-89), and Texas Savings and Loan Associations(1984-90). Kaminsky and Reinhart (1999) referred to the South American financial problem during 1995 and to the Asian Crises during 1997 as Twin Crises. Countries involved in these crises face exchange rate and banking problems simultaneously. In the present paper, we expand the existing literature for South Asian countries to include South Korea, Philippines, Thailand, Malaysia, and Indonesia.

Following Introduction in Section one, Section two presents a literature review. Section three discusses models, section four provides analysis and empirical results, and section four concludes.

\section{Literature Review}

Gruben and McComb (2003) apply the Breshnahan-Shaffer methodology to the Mexican banking sector during the mid-nineties and finds that the Mexican banking system was "super-competitive", that is, marginal prices were set below marginal costs. This was called super-competition where banks are taking risks to capture a larger share of the market today so that tomorrow they can reap the benefits of such hostile expansion.

Gruben et al (1998) study Argentina, Mexico and Canada. They find that lending risk (measured as super-competition stage of banks) increases significantly in the aftermath of liberalization in countries where market discipline is weak. Gruben et al. ( 2003) study six countries ( Argentina, Canada, Mexico, Norway, Singapore and Texas, USA) and find evidence that the measure of bank risk increases significantly in the aftermath of liberalization, but only where depositors fail to discipline banks and also that market discipline and bank risk were persistently inversely related. 
As a result, we attempt to find answers to the following three important questions: (1) does risky lending occur prior to bank Crises; and (2) does lack of market discipline encourage risky lending; and (3) what is the relationship between depositor discipline and bank risk taking behavior. We follow the Breshnan(1982)Shaffer(1989)-Gruben(1999) framework. We intend to extend the study for five South Asian Countries, including Malaysia, Indonesia, Korea, Philippines and Thailand during the Asian Crises period of 1997. We focus directly on the changes immediately before and after financial Crises.

\subsection{Analysis}

Following Gruben et al (2003a,b), we test the existence of depositor discipline: do the depositors punish banks by withdrawing deposits when asset quality declines. If so, then the growth rate of deposits (RTDEPGROW) should be negatively related with asset quality (ASSETQUALITY). We set up the following model for this, where the coefficient $\theta_{1}$ should be negative:

$$
\begin{aligned}
& \text { RTDEPGROW }_{i t}=\theta_{0} \dashv \theta_{1} \text { ASSETQUALITY }_{i t} \dashv \theta_{2} \text { EQTA }_{i t} \dashv \theta_{3} \text { LTA }_{i t} \\
& +\theta_{4} \text { TDTL }_{i t}+\varepsilon_{i t} \ldots \ldots \ldots \ldots \ldots \ldots \ldots \ldots \ldots \ldots \ldots \ldots \ldots \ldots \ldots(1)
\end{aligned}
$$

The proxies for ASSETQUALITY included here are (i) Ratio of Loan Loss Reserve to Gross Loan (LLRG); (ii) Ratio of Loan Loss Provision to Net Internal Reserve (LLLP); (iii) Loan Loss Reserve to Impaired Loan (LLRL); and (iv) Impaired Loan to Gross Loan (ILGL). These variables are used one after another in equation (1) and so the regression is run four times. If depositor discipline exists, then all of these variables should be negatively related with the dependent variable. Appendix A presents the expected signs on this and all subsequent models (equation 9, 10 and 11). 
Equation (1) includes three control variables: EQTA: the ratio of equity capital to total assets. LTA: Log of total assets; and TDTL: a deposit configuration variable. Signs of the coefficients of EQTA and TDTL are ambiguous and should be empirically examined. If depositors prefer an adequately capitalized bank to an undercapitalized bank to the extent that they withdraw their fund from the undercapitalized to the adequately capitalized bank, then the EQTA variable will have a positive relationship with deposit growth. But this needs to be found empirically. Similar implication holds for TDTL. But for LTA, the Log of total assets 'too big to fail' hypothesis implies that bigger banks should be able to attract more deposit due to higher confidence of the depositors.

In the next step, we construct the index of competition using the simultaneous equation model that Shaffer $(1989,1993$, and 1995) introduced. The model tests market power of a commercial banking system by estimating an index of market power $(\lambda)$ and then identifying breaks in competitiveness by applying a dummy variable. To test if the degree of competition has increased following liberalization, that is, whether there is a difference before and after, the dummy variable is set to change value from "zero" to "one" after liberalization.

The index of market power $(\lambda)$ captures the difference between firm's perceived marginal revenue schedule and the firm's demand schedule. Under competitive conditions, marginal cost can be set equal to perceived marginal revenue. If the firm's perceived marginal revenue schedule and the firm's demand schedule are identical, then setting marginal cost equal to perceived marginal revenue is the same as setting marginal cost equal to demand price, which is the condition of perfect competition. But if firms act in collusion, such as, duopoly or to the extreme monopoly, then they set marginal cost equal to perceived marginal revenue that corresponds to the industry's marginal revenue curve.

A demand function for commercial bank services is written as follows: 
$Q=D(P, Y, a)+\varepsilon$

Where $\mathrm{Q}$ is quantity, $\mathrm{P}$ is price, $\mathrm{Y}$ is a vector of exogenous variables, $\alpha$ is a vector of demand equation parameters to be estimated, $\varepsilon$ is a random error term.

Actual (as distinguish from perceived) marginal revenue ${ }^{9}$ is:

$M R=P \dashv h(Q, Y, a)$,

$=P+Q /(\partial Q / \partial P)$

The function $h(Q, Y, a)$ is the inverse of the semi-elasticity of demand ${ }^{10}$, and $h(*) \leq 0$. Firm's perceived marginal revenue is:

$M R^{P}=P+\lambda h(Q, Y, \alpha)$

Where $\lambda$ is a new parameter to be estimated, $0 \leq \lambda \leq 1$. Here, $\lambda$ measures the degree to which firms recognize the distinction between demand and marginal revenue functions.

Let $c(Q, W, \beta)$ be the average firm's marginal cost function, where $\mathrm{W}$ is a vector of exogenous supply side variables and $\beta$ is a vector of supply side parameters to be estimated. Maximizing firms will set perceived marginal revenue equal to marginal cost, or where $\eta$ is a random error term.

${ }_{9} T R=P \cdot Q \Rightarrow \partial T R / \partial Q=M R=P \cdot \partial Q / \partial Q+Q \cdot \partial P / \partial Q=P \cdot+Q \cdot \partial P / \partial Q$

${ }^{10} M R=P+Q /(\partial Q / \partial P)=P+\frac{1}{(\partial Q / \partial P) / Q}=P+\frac{1}{\frac{\partial Q}{Q} \cdot \frac{1}{\partial P}}=P+\frac{1}{\frac{\partial Q}{Q} / \frac{\partial P}{1}}$ 
$P=c(Q, W, \beta)-\lambda h(Q, Y, a)-1 \ldots \ldots \ldots \ldots(5)$

If firms act as price takers so that they do not perceive a difference between their marginal revenue functions and demand function, then $\lambda=0$. If firms act as a joint monopoly $(\lambda=1)$, clearly perceiving a difference between their demand and marginal revenue functions, they set output where marginal cost equals marginal revenue. Intermediate values of $\lambda$ correspond to other oligopoly solution concepts. A Cournot equilibrium is suggested when $\lambda=1 / \mathrm{n}$.

To estimate $\lambda$, it is necessary to estimate simultaneously specifications of both (2) and (5), treating $\mathrm{P}$ and $\mathrm{Q}$ as endogenous variables. The demand function (2) is specified as:

$Q=a_{0}+a_{1} P \dashv a_{2} Y+a_{3} P Z \dashv a_{4} Z+a_{5} P Y \dashv a_{6} Y Z+\varepsilon$

Where $\mathrm{Q}$ is output quantity, $\mathrm{P}$ is output price, $\mathrm{Y}$ is a measure of macroeconomic activity, assumed to be an exogenous variable, and $\mathrm{Z}$ is the price of a substitute for bank output, also assumed to be exogenous. The interaction terms, the products PZ, PY and YZ, are necessary to permit rotation of the demand curve as required to identify $\lambda$.

Following the model of Shaffer (1993), a translog cost function is used to estimate the average commercial bank's cost function as follows:

$\ln C=\gamma_{0}+\gamma_{1} \ln Q+\gamma_{2}(\ln Q)^{2}+\gamma_{3} \ln W_{1}+\gamma_{4} \ln W_{2}+\gamma_{5} \ln \left(W_{1}\right)^{2} / 2+\gamma_{6} \ln \left(W_{2}\right)^{2 / 2}$ $+\gamma_{7} \ln W_{1} \ln W_{2}+\gamma_{8} \ln Q \ln W_{1}+\gamma_{9} \ln Q \ln W_{2} \ldots \ldots .(7)$ 
Where $\mathrm{C}$ is total cost, $\mathrm{W}_{1}$ and $\mathrm{W}_{2}$ are exogenous input prices, as explained below.

Equation (7) gives rise to the following marginal cost function, $c(Q, W, \beta)$

$M C=(C / Q)\left(\beta_{1}+\beta_{2} \ln Q \dashv \beta_{3} \ln W_{1} \dashv \beta_{4} \ln W_{2}\right)+1$

Therefore, equation (5) is specified as follows

$P=-\lambda Q /\left(a_{1} \dashv a_{3} Z \dashv a_{5} Y\right) \dashv(C / Q)\left(\beta_{1} \dashv \beta_{2} \ln Q \dashv \beta_{3} \ln W_{1} \dashv \beta_{4} \ln W_{2}\right) \dashv \xi$

Based on this equation, in the first step, the value of $-\lambda$ represents a typical bank's percentage deviation of output from competitive level. This $-\lambda$ is smaller than zero implies that output is below the competitive levels. If $\lambda$ is zero it implies that output is at the competitive level. And $-\lambda$ larger than zero implies that output exceeds that of competitive levels. This is called "super-competition". This means that banks are operating at a point where marginal cost is larger than perceived marginal benefit.

However, equation (9) is not configured to facilitate analysis of breaks in bank behavior. To allow for breaks, we rely on the following specification of (6):

$$
\begin{aligned}
& P=-\lambda Q /\left(a_{1} \dashv a_{3} Z \dashv a_{5} Y\right) \dashv(C / Q)\left(\beta_{1} \dashv \beta_{2} \ln Q \dashv \beta_{3} \ln W_{1} \dashv \beta_{4} \ln W_{2}\right) \\
& -\beta_{5} D Q /\left(\alpha_{1}+\alpha_{3} Z+\alpha_{5} Y\right)+\xi
\end{aligned}
$$

Where $\mathrm{D}$ is a dummy variable to be more fully explained below and $\xi$ is a random error term. The system of equation represented by (6) and (10) is then estimated simultaneously with 3SLS.

The difference of competition between the two periods, if reflected in the coefficient on the dummy variable $\beta_{5}$. Before the liberalization date the index of market power will be $\lambda$, but afterwards it will be $\lambda+\beta_{5}$. Thus $\beta_{5}$ shows the difference between the levels of competition between the two periods. If we find that 
the value of $\beta_{5}$ is negative and large, that will imply that banks significantly increased the riskiness of its behavior after liberalization or privatization. Appendix A presents the signs on these equations (9 and 10).

As we have already pointed out, Gruben et al. (2003) examined the relationship between depositor discipline and the structural break in the direction of super-competitiveness with the help of graphical representations. In the first representation, t-statistics associated with the past-due-loans-to-total-assets ${ }^{11}$ (indicator of depositor discipline) ratio were plotted on the horizontal axis against the index of competition (coefficient $\beta_{5}$ in equation 10) on the vertical axis. In the next graph, t-statistics associated with the past-due-loans-to-total-assets ratio ${ }^{12}$ were plotted on the horizontal axis against the t-statistics of the same index of competition (coefficient $\beta_{5}$ in equation 10).

The Panzer and Rosse $(1982,1987)$ (henceforth PR) approach is used to assess the competitive nature of banking industries starting from 1998. The PR Hstatistic, which will be our index of competition, is calculated from reduced form bank revenue equations. It measures the sum of the elasticities of the total revenue of the banks with respect to the bank's input prices. The PR H-statistic is adopted from Claessens et al. (2003) and its values and interpretations are presented in Table A below ${ }^{13}$.

Table A: PR H-statistics

\begin{tabular}{|c|c|}
\hline Value of PR H-statistics & Decision \\
\hline $\mathrm{H}<0$ & Monopoly \\
\hline $\mathrm{H}=1$ & Perfect Competition \\
\hline $0<\mathrm{H}<1$ & Monopolistic Competition \\
\hline
\end{tabular}

\footnotetext{
${ }^{11}$ This t-statistics was multiplied by negative one.

${ }^{12}$ This t-statistics was multiplied by negative one.

13 These values and interpretation assume that the tests are undertaken on observations that are in long-run equilibrium.
} 
Again in line with Claessens et al. (2003), the following reduced-form revenue equation is estimated on pooled samples for each country to derive the Hstatistics

$$
\begin{aligned}
& \ln \left(P_{i t}\right)=a+\beta_{1} \ln \left(W_{1, i t}\right) \dashv \beta_{2} \ln \left(W_{2, i t}\right)+\beta_{3} \ln \left(W_{3, i t}\right) \dashv \\
& \gamma_{1} \ln \left(Y_{1, i t}\right)+\gamma_{2} \ln \left(Y_{2, i t}\right)+\gamma_{3} \ln \left(Y_{3, i t}\right)+\varepsilon_{i t} \ldots \ldots \ldots \ldots \ldots \ldots \ldots \ldots \ldots \ldots \ldots \ldots \ldots \ldots \ldots
\end{aligned}
$$

Here, $P_{i t}$ is the ratio of gross interest revenue to total assets (proxy for output price of loans), $W_{1, i t}$ is the ratio of interest expense to total deposits and money market funding ( proxy for input price of deposits), $W_{2, i t}$ is the ratio of personnel expense to total assets ( proxy for input price of labor), $W_{3, i t}$ is the ratio of other operating and administrative expense to total assets ( proxy for input price of equipment / fixed capital). The subscript $\mathrm{i}$ and $\mathrm{t}$ denote banks and year, respectively.

Three control variables are also included in the model $Y_{1, i t}$, which is the ratio of equity to total assets. $Y_{2, \text { it }}$ is the ratio of net loans to total assets. $Y_{3, i t}$ is the logarithm of total assets ( to control for potential size effect). Natural logarithm of each variables is taken.

The model is estimated using different techniques: (i) bank specific intercept with fixed effect; (ii) random effect; (iii) between effect; and (iv) OLS on pooled data. Also we run the regressions across countries and across years.

All data for bank specific variables come from Bank Scope CD, 2005. All macro-economic variables come from World Development Indicators, 2005.

\section{Empirical Results}

We present the summary statistics in Table 1 of the Data Appendix. Panel a presents summary statistics for variables used in the Gruben (2003) model. The 
sample period covers 1992-2004. We test for a break in competitive behavior between 1992-1995 and 1996-2004. Source of data are given in Table 1 of Appendix.

On the other hand, panel $b$ of Table 1 presents summary statistics for the variables used in the depositor discipline regressions for the period 1996-2004. Table 2 presents similar panels for the correlation between variables.

Table 3 presents OLS regression results for equation 1. The equation tests for the existence of depositor discipline in the selected five South Asian countries to see if the depositors withdraw their deposits when asset quality of banks declines. For this part we alternatively tested with three different dependent variables: (i) deposit growth rate; (ii) total deposit; and (iii) total deposit divided by total assets. We present only the last one and the others are available on request. On the other hand, we also tested with four alternative definitions of asset quality: namely (i) ratio of loan loss reserve to gross loan (LLRG) presented in panel a; (ii) ratio of loan loss provision to net internal reserve (LLLP) - panel b; (iii) ratio of impaired loan to gross loan (ILGL) - panel c; and (iv) ratio of loan loss reserve to impaired loan (LLRL) - panel d. In total, four sets of regressions were run on equation 1 for each of the five countries.

Overall, we found that the state of depositor discipline was very weak. Most of the asset quality proxies had insignificant coefficients, and even when they were significant, the coefficients were very low / close to zero, indicating the impact if very small. As a result, we conclude that total deposits scaled by total assets are probably not related to changes in asset quality. Given the role of government guarantees, this is hardly surprising. This can be supported by the recent findings of Mondschean et al (1998) in the case of Poland. These authors find that use of explicit deposit guarantees starting in late 1994 has removed the use of market discipline as a check on these banks behavior. Before the deposit guarantee program depositors extracted a price of risk, but after the program was initiated that stopped. 
Table 4 presents estimates based on simultaneous estimation of Shaffer Model given in equations 6 and 10. None of the lambda coefficients in the five countries are significant. This implies that the coefficient is statistically equal to zero, indicating perfect competition. The evidence is in line with Gruben et al. (1997, 1998, 2003) papers. Similarly, beta five coefficients are all insignificant indicating to a no change in competitive behavior of banks before and after 1996.

In Table 5, we combine the index of competition from Table 4 (panel a), with the index of depositor discipline (panel $b$ - coefficient of proxy for asset quality) in Table 3 in order to test the link between the two. Several alternative plots are tested but results do not show any definite relationship between the two indexes. As a result, we do not find evidence suggested by Gruben et al (2003) that these were inversely related. Therefore, we fail to establish that in the absence or in the presence of weak depositor discipline, banks tend to take higher risks as those papers concluded.

Table 6, shows the results for the PR-methodology (H-statistics) across countries and across years. Value of the H-statistics (between zero and one) shows evidence of collusion among banks in the different countries.

Table 7, shows the value of H-statistics for each country between 1996-2004, across different estimation techniques. Parameters estimated with OLS are smallest, whereas those estimated with Fixed Effect are the highest. But random effect results are in the middle. But all these values are less than one, which is again indication of collusive behavior in the banking sector of these countries.

\section{Conclusions}

The present study provides evidence on the behavior of banks with respect to risk taking and strength of depositor discipline within the context of South East Asian Crises of 1997. The results are in line with that of Gurben $(1998,2003)$ and other studies. Even in the after-math of Asian Crises, the strength of depositor discipline (tested as a negative 
relationship between depositor discipline and assets quality) was absent. Depositors as a group did not withdraw deposits from banks in reaction to a decline in their asset quality. This also highlights the importance of the need to improve measures that strengthen depositor discipline, such as, the measures put forward in Basel II. Timely and accurate dissemination of information can go a long way to solve these problems. Overall, any measure that enhances transparency and accountability of the decision making of banks is welcome. These are some of the objectives of Basel II.

For the test of a break in the competitive behavior of banks before and after 1996, we find no change in banks' risk-taking behavior before and after the crisis. Also the index has a value of zero, implying competitive behavior of banks in these countries. This to is in line with Gruben et al. $(1998,2003)$. However, use of PR-methodology to measure bank competitive behavior indicates the monopolistic competition and not perfect competition exists in these markets.

However, we did not find a consistent link between depositor discipline and bank risk taking, which can be explained by the weak state of depositor discipline. At least until today depositor discipline has not grown strong enough to affect banks risk-taking behavior. More needs to be done to make depositor discipline effective. 


\section{Data Appendix}

Table 1: Summary Statistics

Panel a: Shaffer (1993) Model (1992-2004)

\begin{tabular}{|c|c|c|c|}
\hline & Total Equity & Total Assets & Total Deposits \\
\hline Mean & 646058.43 & 7379065.01 & 5266561.11 \\
\hline Standard Error & 25500.37 & 296119.35 & 210790.18 \\
\hline \multirow[t]{2}{*}{ Count } & 3189 & 3293 & 3184 \\
\hline & Interest Income & Personnel Expenditure & Interest Expense \\
\hline Mean & 504155.48 & 53167.15 & 368801.13 \\
\hline Standard Error & 19751.19 & 2386.73 & 14935.11 \\
\hline \multirow{2}{*}{ Count } & 3163 & 2878 & 3103 \\
\hline & Total Liability & Domestic Interest Rate & Gross Domestic Product \\
\hline Mean & 6905545.19 & 8.99 & 189556512157.73 \\
\hline Standard Error & 280954.99 & 0.08 & 2110472705 \\
\hline Count & 3293 & 5909 & 5909 \\
\hline
\end{tabular}

Panel b: Depositor Discipline Model (1996-2004)

\begin{tabular}{|l|c|c|c|c|}
\hline & Total Assets & Total Deposits & $\begin{array}{c}\text { Loan Loss } \\
\text { Reserve to Gross } \\
\text { Loan }\end{array}$ & $\begin{array}{c}\text { Loan Loss } \\
\text { Provision to Net } \\
\text { Interest Reserve }\end{array}$ \\
\hline Mean & 8106025.67 & 6152171.87 & 8.50 & 17414547.49 \\
\hline Standard Error & 345885.36 & 259475.49 & 0.23 & 3979779.27 \\
\hline Count & 2760 & 2684 & 2467 & 2341 \\
\hline \multicolumn{5}{|c|}{} \\
\hline \multicolumn{5}{|c|}{} \\
\hline Mean & $\begin{array}{c}\text { Loan Loss } \\
\text { Reserve to } \\
\text { Impaired Loan }\end{array}$ & $\begin{array}{c}\text { Impaired Loan to } \\
\text { Gross Loan }\end{array}$ & Total Liability & Total Equity \\
\hline Standard Error & 39812951.70 & 11.31 & 7582091.67 & 515129.79 \\
\hline Count & 6867921.15 & 0.37 & 327915.60 & 22508.67 \\
\hline
\end{tabular}


Table 2: Correlation Matrix

Panel a: Shaffer (1993) Model (1992-2004)

\begin{tabular}{|l|c|c|c|c|c|c|c|c|c|}
\hline & $\begin{array}{c}\text { Total } \\
\text { Equity }\end{array}$ & $\begin{array}{c}\text { Total } \\
\text { Assets }\end{array}$ & $\begin{array}{c}\text { Total } \\
\text { Deposits }\end{array}$ & $\begin{array}{c}\text { Interest } \\
\text { Income }\end{array}$ & $\begin{array}{c}\text { Personnel } \\
\text { Income }\end{array}$ & $\begin{array}{c}\text { Interest } \\
\text { Expendit } \\
\text { ure }\end{array}$ & $\begin{array}{c}\text { Total } \\
\text { Liability }\end{array}$ & $\begin{array}{c}\text { Domestic } \\
\text { Interest } \\
\text { Rate }\end{array}$ & $\begin{array}{c}\text { Gross } \\
\text { Domestic } \\
\text { Product }\end{array}$ \\
\hline Total Equity & 1.00 & & & & & & & & \\
\hline Total Assets & 0.85 & 1.00 & & & & & & & \\
\hline $\begin{array}{l}\text { Total } \\
\text { Deposits }\end{array}$ & 0.84 & 0.96 & 1.00 & & & & & & \\
\hline $\begin{array}{l}\text { Interest } \\
\text { Income }\end{array}$ & 0.93 & 0.90 & 0.92 & 1.00 & & & & & \\
\hline $\begin{array}{l}\text { Personnel } \\
\text { Income }\end{array}$ & 0.82 & 0.91 & 0.93 & 0.87 & 1.00 & & & & \\
\hline $\begin{array}{l}\text { Interest } \\
\text { Expenditure }\end{array}$ & 0.93 & 0.83 & 0.85 & 0.96 & 0.75 & 1.00 & & & \\
\hline $\begin{array}{l}\text { Total } \\
\text { Liability }\end{array}$ & 0.85 & 0.99 & 0.96 & 0.91 & 0.91 & 0.83 & 1.00 & & \\
\hline $\begin{array}{l}\text { Domestic } \\
\text { Interest Rate }\end{array}$ & -0.05 & -0.14 & -0.16 & -0.10 & -0.14 & -0.06 & -0.13 & 1.00 & \\
\hline $\begin{array}{l}\text { Gross } \\
\text { Domestic } \\
\text { Product }\end{array}$ & 0.55 & 0.53 & 0.50 & 0.52 & 0.57 & 0.52 & 0.53 & -0.04 & 1.00 \\
\hline
\end{tabular}


Panel b: Depositor Discipline Model (1996-2004)

\begin{tabular}{|c|c|c|c|c|c|c|c|c|}
\hline & $\begin{array}{c}\text { Total } \\
\text { Assets }\end{array}$ & $\begin{array}{c}\text { Total } \\
\text { Deposits }\end{array}$ & $\begin{array}{l}\text { Loan } \\
\text { Loss } \\
\text { Reserve } \\
\text { to Gross } \\
\text { Loan }\end{array}$ & $\begin{array}{l}\text { Loan Loss } \\
\text { Provision } \\
\text { to Net } \\
\text { Internal } \\
\text { Reserve }\end{array}$ & $\begin{array}{c}\text { Loan Loss } \\
\text { Reserve to } \\
\text { Impaired } \\
\text { Loan }\end{array}$ & $\begin{array}{l}\text { Impaired } \\
\text { Loan to } \\
\text { Gross } \\
\text { Loan }\end{array}$ & $\begin{array}{c}\text { Total } \\
\text { Liabilities }\end{array}$ & $\begin{array}{c}\text { Total } \\
\text { Equity }\end{array}$ \\
\hline Total Assets & 1.00 & & & & & & & \\
\hline Total Deposits & 0.97 & 1.00 & & & & & & \\
\hline $\begin{array}{lll}\text { Loan Loss } & \text { Reserve to } \\
\text { Gross Loan } & & \\
\end{array}$ & -0.13 & -0.12 & 1.00 & & & & & \\
\hline $\begin{array}{l}\text { Loan Loss Provision to } \\
\text { Net Internal Reserve }\end{array}$ & -0.02 & -0.02 & 0.10 & 1.00 & & & & \\
\hline $\begin{array}{l}\text { Loan Loss Reserve to } \\
\text { Impaired Loan }\end{array}$ & -0.05 & -0.05 & 0.23 & 0.04 & 1.00 & & & \\
\hline $\begin{array}{l}\text { Impaired Loan to Gross } \\
\text { Loan }\end{array}$ & -0.10 & -0.09 & 0.51 & 0.10 & -0.13 & 1.00 & & \\
\hline Total Liabilities & 1.00 & 0.97 & -0.12 & -0.02 & -0.05 & -0.10 & 1.00 & \\
\hline Total Equity & 0.80 & 0.75 & -0.16 & -0.05 & -0.05 & -0.13 & 0.77 & 1.00 \\
\hline
\end{tabular}


Table 3: Depositor Discipline (1996-2004)

\begin{tabular}{|c|c|c|c|c|c|c|c|c|c|c|}
\hline & Estimate & P-value & Estimate & P-value & Estimate & P-value & Estimate & P-value & Estimate & P-value \\
\hline & \multicolumn{2}{|c|}{ Indonesia } & \multicolumn{2}{|c|}{ Korea } & \multicolumn{2}{|c|}{ Malaysia } & \multicolumn{2}{|c|}{ Philippines } & \multicolumn{2}{|c|}{ Thailand } \\
\hline \multicolumn{11}{|c|}{ Panel a: Asset Quality Proxy: Loan Loss Reserve to Gross Loan Ratio ( LLRG) } \\
\hline LLRG & 0.01 & 0.57 & 0.01 & $0.00 * * *$ & 0.01 & $0.00 * * *$ & 0.01 & 0.53 & 0.01 & 0.15 \\
\hline LTA & 0.01 & $0.02 * *$ & 0.01 & $0.00 * * *$ & 0.01 & 0.81 & 0.01 & $0.00 * * *$ & 0.01 & $0.02 * *$ \\
\hline EQTA & -0.67 & $0.00 * * *$ & -0.34 & $0.00 * * *$ & -0.73 & $0.00 * * *$ & -0.57 & $0.00 * * *$ & -0.64 & $0.00 * * *$ \\
\hline TDTL & 0.91 & $0.00 * * *$ & 0.90 & $0.00 * * *$ & 0.62 & $0.00 * * *$ & 0.79 & $0.00 * * *$ & 0.84 & $0.00 * * *$ \\
\hline cons & 0.01 & 0.47 & -0.02 & 0.57 & 0.33 & $0.00 * * *$ & -0.04 & 0.18 & 0.06 & $0.01 * * *$ \\
\hline \multicolumn{11}{|c|}{ Panel b: Asset Quality Proxy: Loan Loss Provision to Net Internal Reserve ( LLRP) } \\
\hline LLRP & 0.01 & 0.97 & 0.01 & 0.55 & 0.01 & 0.75 & 0.01 & 0.74 & 0.01 & 0.30 \\
\hline LTA & 0.01 & $0.00 * * *$ & 0.01 & $0.00 * * *$ & 0.01 & 0.46 & 0.01 & $0.01 * * *$ & 0.01 & $0.00 * * *$ \\
\hline EQTA & -0.63 & $0.00 * * *$ & -0.41 & $0.00 * * *$ & -0.71 & $0.00 * * *$ & -0.71 & $0.00 * * *$ & -0.58 & $0.00 * * *$ \\
\hline TDTL & 0.90 & $0.00 * * *$ & 0.86 & $0.00 * * *$ & 0.67 & $0.00 * * *$ & 0.70 & $0.00 * * *$ & 0.84 & $0.00 * * *$ \\
\hline cons & 0.00 & 0.99 & -0.01 & 0.83 & 0.27 & $0.00 * * *$ & 0.19 & $0.00 * * *$ & 0.04 & 0.18 \\
\hline \multicolumn{11}{|c|}{ Panel c: Asset Quality Proxy: Impaired Loan to Gross Loan ( ILGL) } \\
\hline ILGL & 0.01 & 0.41 & 0.01 & $0.00 * * *$ & 0.01 & $0.02 * *$ & 0.01 & 0.46 & 0.01 & 0.26 \\
\hline LTA & 0.01 & 0.14 & 0.01 & 0.16 & 0.01 & 0.61 & 0.01 & $0.00 * * *$ & 0.01 & 0.65 \\
\hline $\begin{array}{l}\text { EQTA } \\
\end{array}$ & -0.71 & $0.00 * * *$ & -0.74 & $0.00 * * *$ & -0.73 & $0.00 * * *$ & -0.66 & $0.00 * * *$ & -0.82 & $0.00 * * *$ \\
\hline TDTL & 0.93 & $0.00 * * *$ & 0.92 & $0.00 * * *$ & 0.67 & $0.00 * * *$ & 0.73 & $0.00 * * *$ & 0.90 & $0.00 * * *$ \\
\hline cons & 0.01 & 0.76 & 0.08 & $0.00 * * *$ & 0.29 & $0.00 * * *$ & 0.11 & $0.00 * * *$ & 0.08 & $0.00 * * *$ \\
\hline \multicolumn{11}{|c|}{ Panel d: Asset Quality Proxy: Loan Loss Reserve to Impaired Loan ( LLRL) } \\
\hline LLRL & 0.01 & 0.75 & 0.01 & $0.00 * * *$ & 0.01 & $0.06^{*}$ & 0.01 & 0.52 & 0.01 & 0.96 \\
\hline LTA & 0.01 & 0.22 & 0.01 & $0.00 * * *$ & 0.01 & 0.73 & 0.01 & $0.01 * * *$ & 0.01 & 0.57 \\
\hline EQTA & -0.72 & $0.00 * * *$ & -0.67 & $0.00 * * *$ & -0.75 & $0.00 * * *$ & -0.81 & $0.00 * * *$ & -0.83 & $0.00 * * *$ \\
\hline TDTL & 0.93 & $0.00 * * *$ & 0.93 & $0.00 * * *$ & 0.71 & $0.00 * * *$ & 0.81 & $0.00 * * *$ & 0.90 & $0.00 * * *$ \\
\hline cons & 0.01 & 0.59 & 0.09 & $0.00 * * *$ & 0.24 & $0.00 * * *$ & 0.12 & $0.00 * * *$ & 0.08 & $0.00 * * *$ \\
\hline
\end{tabular}

Note: In the table we present the estimates of equation 1.1 (reproduced below). Focus is on the coefficients of the proxies for asset quality. If the coefficients are significant and negative we have evidence of depositor discipline. On the other hand, if they are not then we do not have evidence.

$R T D E P G R O W_{i t}=\theta_{0} \dashv \theta_{1}$ ASSETQUALITY $_{i t} \dashv \theta_{2}$ EQTA $_{i t} \dashv \theta_{3}$ LTA $_{i t} \dashv \theta_{4}$ TDTL $_{i t} \dashv \varepsilon_{i t}$

In the above, table we do not get evidence.

'***' significant at the .01 percent level; '**' significant at the .05 percent level; and '*' significant at the .10 percent level. 
Table 4: Shaffer Model (3SLS)

\begin{tabular}{|c|c|c|c|c|c|c|}
\hline & Indonesia & & Korea & & Malaysia & \\
\hline Parameter & Estimate & P-value & Estimate & P-value & Estimate & P-value \\
\hline A0 & $\begin{array}{r}3663300000.0 \\
0 \\
\end{array}$ & 0.43 & $\begin{array}{r}41352400000 . \\
00 \\
\end{array}$ & 0.46 & $\begin{array}{r}3695140000.0 \\
0 \\
\end{array}$ & 0.18 \\
\hline A1 & $\begin{array}{r}21201800000 . \\
00 \\
\end{array}$ & 0.38 & $\begin{array}{r}39911400000 \\
0.00 \\
\end{array}$ & 0.49 & $\begin{array}{r}7062300000.0 \\
0 \\
\end{array}$ & 0.46 \\
\hline $\mathrm{A} 2$ & -0.02 & 0.44 & 0.07 & 0.45 & 0.04 & 0.18 \\
\hline A3 & 104493000.00 & 0.38 & $\begin{array}{r}- \\
9495410000.0 \\
0\end{array}$ & 0.49 & $401842000.00^{-}$ & 0.87 \\
\hline A4 & -87230300.00 & 0.53 & $\begin{array}{r}2530900000.0 \\
0 \\
\end{array}$ & 0.43 & 856990000.00 & 0.13 \\
\hline A5 & 0.11 & 0.38 & -0.62 & 0.49 & 0.09 & 0.42 \\
\hline A6 & 0.00 & 0.55 & 0.00 & 0.40 & -0.01 & 0.15 \\
\hline LAMBDA & 0.01 & 0.73 & 0.01 & 0.73 & 0.01 & 0.86 \\
\hline B1 & -21.01 & 0.72 & -9.97 & 0.42 & -2.18 & $0.00^{* * *}$ \\
\hline B2 & -9.35 & 0.72 & -1.18 & 0.41 & 0.25 & $0.00 * * *$ \\
\hline B3 & -0.38 & 0.91 & -2.78 & 0.42 & 0.07 & $0.00 * * *$ \\
\hline B4 & -7.82 & 0.69 & -0.41 & 0.41 & -0.02 & 0.49 \\
\hline B5 & 0.00 & 0.75 & 0.00 & 0.38 & 0.00 & 0.83 \\
\hline
\end{tabular}

Note: As mentioned in the text, LAMBDA (equation 1.10) is the index of competition adopted from Gruben et al (1997, 1998, and 2003). Beta five (last row) is the dummy variable to test the structural break at 1996, where it takes a value of 0 before that year and 1 afterwards.

$Q=a_{0} \dashv a_{1} P \dashv a_{2} Y \dashv a_{3} P Z \dashv a_{4} Z \dashv a_{5} P Y \dashv a_{6} Y Z \dashv \varepsilon$

$P=-\lambda Q /\left(a_{1} \dashv a_{3} Z \dashv a_{5} Y\right) \dashv(C / Q)\left(\beta_{1} \dashv \beta_{2} \ln Q \dashv \beta_{3} \ln W_{1} \dashv \beta_{4} \ln W_{2}\right)-\beta_{5} D Q /\left(a_{1} \dashv a_{3} Z \dashv a_{5} Y\right) \dashv \xi \ldots$

'***' significant at the .01 percent level; '**' significant at the .05 percent level; and '*' significant at the .10 percent level. 
Table 4: Shaffer Model (3SLS)

\begin{tabular}{|c|c|c|c|c|}
\hline \multirow[b]{2}{*}{ Parameter } & \multicolumn{2}{|c|}{ Philippines } & \multicolumn{2}{|c|}{ Thailand } \\
\hline & Estimate & P-value & Estimate & P-value \\
\hline A0 & 2737210000.00 & 0.68 & -2477920000.00 & 0.28 \\
\hline A1 & -14061400000.00 & 0.70 & 32912800000.00 & 0.36 \\
\hline A2 & -0.04 & 0.68 & 0.02 & 0.29 \\
\hline A3 & 50367700.00 & 0.72 & -13602900.00 & 0.98 \\
\hline A4 & -187742000.00 & 0.67 & -77500800.00 & 0.72 \\
\hline A5 & 0.19 & 0.72 & -0.27 & 0.37 \\
\hline A6 & 0.00 & 0.67 & 0.00 & 0.66 \\
\hline LAMBDA & 0.01 & 0.70 & 0.00 & 0.61 \\
\hline B1 & 1.10 & $0.00 * * *$ & -5.37 & $0.00 * * *$ \\
\hline B2 & -0.27 & $0.00 * * *$ & -2.38 & $0.00 * * *$ \\
\hline B3 & -0.47 & $0.00 * * *$ & -1.10 & $0.00 * * *$ \\
\hline B4 & 0.24 & $0.01 * * *$ & -1.13 & $0.00 * * *$ \\
\hline B5 & 0.00 & 0.70 & 0.00 & 0.57 \\
\hline
\end{tabular}

'***' significant at the .01 percent level; '**' significant at the .05 percent level; and '*' significant at the .10 percent level. 
Table 5: Index of Competition and Index of Depositor Discipline Combined (1996-2004)

\begin{tabular}{|c|c|c|c|c|c|}
\hline & Indonesia & Korea & Malaysia & Philippines & Thailand \\
\hline \multicolumn{6}{|c|}{ Panel a: Index of Competition } \\
\hline $\begin{array}{c}\text { BETA FIVE } \\
-3 \text { SLS }\end{array}$ & .01 & .01 & .01 & .01 & .01 \\
\hline \multicolumn{6}{|c|}{ Panel b: Index of Depositor Discipline } \\
\hline $\begin{array}{l}\text { Loan Loss } \\
\text { Reserve to } \\
\text { Gross Loan }\end{array}$ & .01 & .01 & .01 & .01 & .01 \\
\hline $\begin{array}{l}\text { Loan Loss } \\
\text { Provision to } \\
\text { Net Internal } \\
\text { Reserve }\end{array}$ & .01 & .01 & .01 & .01 & .01 \\
\hline $\begin{array}{l}\text { Impaired } \\
\text { Loan to Gross } \\
\text { Loan }\end{array}$ & .01 & .01 & .01 & .01 & .01 \\
\hline $\begin{array}{lr}\text { Loan } & \text { Loss } \\
\text { Reserve } & \text { to } \\
\text { Impaired } & \\
\text { Loan } & \\
\end{array}$ & .01 & .01 & .01 & .01 & .01 \\
\hline
\end{tabular}


Table 6: H-Statistics by Year: Based On OLS on Pooled Data

\begin{tabular}{|c|c|c|c|c|c|}
\hline & Indonesia & Korea & Malaysia & Philippines & Thailand \\
\hline 1996 & 0.528172 & 0.26573 & 0.486995 & 0.654482 & 0.602894 \\
\hline 1997 & 0.635845 & -0.03035 & 0.411681 & 0.482115 & 0.515969 \\
\hline 1998 & 0.510343 & 0.267491 & 0.316997 & 0.552204 & -0.07948 \\
\hline 1999 & 0.366977 & 0.122206 & 0.499227 & 0.303658 & 0.105174 \\
\hline 2000 & 0.134637 & 0.100838 & 0.697793 & 0.266163 & 0.287981 \\
\hline 2001 & 0.176368 & -0.01734 & 0.265414 & 0.059796 & 0.579978 \\
\hline 2002 & 0.444437 & 0.064629 & 0.609935 & 0.387675 & 0.934896 \\
\hline 2003 & 0.407129 & 0.267886 & 0.211135 & 0.368492 & 1.414202 \\
\hline 2004 & NA & 0.231417 & -1.49969 & 0.602894 & 0.824391 \\
\hline
\end{tabular}

Note: This is the estimate of $\mathrm{H}$-statistics given in equation 1.11.

$$
\ln \left(P_{i t}\right)=a+\beta_{1} \ln \left(W_{1, i t}\right)+\beta_{2} \ln \left(W_{2, i t}\right)+\beta_{3} \ln \left(W_{3, i t}\right)+\gamma_{1} \ln \left(Y_{1, i t}\right)+\gamma_{2} \ln \left(Y_{2, i t}\right)+\gamma_{3} \ln \left(Y_{3, i t}\right)+\varepsilon
$$

Here, the dependent variable $P_{i t}$ is the ratio of gross interest revenue to total assets (proxy for output price of loans). The independent variables are: $W_{1, i t}$ is the ratio of interest expense to total deposits and money market funding (proxy for input price of deposits), $W_{2, i t}$ is the ratio of personnel expense to total assets ( proxy for input price of labor), $W_{3, i t}$ is the ratio of other operating and administrative expense to total assets ( proxy for input price of equipment, fixed capital etc). Three control variables are also included in the model: $Y_{1, i t}$ is the ratio of equity to total assets, $Y_{2, i t}$ is the ratio of net loans to total assets, and $Y_{3, i t}$ is the logarithm of total assets ( to control for potential size effect). Natural logarithm of all variables is taken. 
Table 7: H-Statistics by Country: Based On Several Estimation Techniques (Sample Period 1996-2004)

\begin{tabular}{|c|c|c|c|c|}
\hline & Fixed Effect & $\begin{array}{c}\text { Random } \\
\text { Effect }\end{array}$ & Between Effect & OLS \\
\hline Indonesia & 0.81 & 0.69 & 0.58 & 0.60 \\
\hline Korea & 0.49 & 0.48 & 0.00 & 0.26 \\
\hline Malaysia & 0.70 & 0.65 & 0.49 & 0.55 \\
\hline Philippines & 0.82 & 0.72 & 0.4 & 0.58 \\
\hline Thailand & 0.82 & 0.85 & 1.27 & 0.90 \\
\hline
\end{tabular}

Note: Due to lack of enough observations we could not replicate this for each year in each country. These are the second set of estimates of equation (11). Details are presented in Table 6. 


\section{References}

Angeline, Paolo and Nicola Cetorelli (2003), "The Effects of Regulatory Reform on Compeititon in the Banking Industry," Journal of Money, Credit and Banking, Vol. 35, No. 5 (October, 2003).

Barth, James R., Gerard Caprio Jr., and Ross Levine (2003). "Bank Regulation and Supervision: What Works Best?” Journal of Financial Intermediation, forthcoming.

Barth, James R., Gerard Caprio, Jr. and Ross Levine (2002). "Financial Regulation and Performance: Cross-Country Evidence,” Banking, Financial Integration, and International Crises.

Baumol, William J., John C. Panzer, and Robert D. Willig (1982). “Contestable Markets and the Theory of Industry Structure." San Diego, CA: Harcourt Brace Jovanovich.

Bikker, A. Jacob and Katharina Haaf (2001). "Competition, concentration, and their relationships: an empirical analysis of the banking industry," De Nederlandsche Bank (DNB), Working Paper.

Boehmer, Ekkehart (2004), "Bank Privatization in Developing and Developed Countries: Cross-sectional Evidence on the Impact of Economic and Political Factors," Paper presented at the 2003 World Bank Conference on Bank Privatization.

Bresnahan, Timothy, 1982, "The Oligopoly Solution is identified.” Econometric Letters 10, 87-92.

Calomiris, Charles W. (1990) "Is Deposit Insurance Necessary?: A Historical Perspective," The Journal of Economic History, 283-95.

Center for Latin American Economics 2003 Annual Report, Research Department, Federal Reserve Bank of Dallas.

Claessens, Stijn and Luc Laeven. (2003) "Competition in the Financial Sector and Growth: A Cross-Country Perspective," World Bank

Claessens, Stijn and Luc Laeven. (2003) "What Drives Bank Competition? Some Empirical Questions," Policy Research Paper, 3111.

Current Strength of the U.S. Banking Sector, Federal Reserve Banks of San Francisco, Economic Letter, 2003 - 37 ( December).

Daniel, C. Betty and John Bailey Jones (2004) "Financial Liberalization and Banking Crises in Emerging Economies," Working Paper. 
Demirguc-Kunt, Asli and Enrica Detragiache (2005) "Cross-Country Empirical Studies of Systematic Bank Distress: A Survey,” International Monetary Bank, Working Paper 96.

Demirguc-Kunt, Asli and Enrica Detragiache (1998a) "The Determinants of Banking Crises: Evidence from Developing and Developed Countries," International Monetary Bank, Staff Papers, Vol. 45, pp.81-109.

Demirguc-Kunt, Asli and Enrica Detragiache (1998b) "Financial Liberalization and Financial Fragility,” International Monetary Bank Working Paper, WP/98/81.

Demirguc-Kunt, Asli and Enrica Detragiache (2000a) "Does Deposit Insurance Increase Banking System Stability?,” IMF Working Paper, 00/01.

Demirguc-Kunt, Asli and Enrica Detragiache (2000b) "Monitoring Banking Sector Fragility: A Multivariate Logit Approach," World Bank Economic Review, Vol. 14, No. 2, pp. 287-307.

Demirguc-Kunt, Asli, Luc Laeven and Ross Levine (2003) "Regulations, Market Structure, Institutions, and the Cost of Financial Intermediation", Working Paper 9890, National Bureau of Economic Research.

de la Cuadra, Sergio and Salvador Valdes ( 1992)"Myths and Facts About Financial Liberalization in Chile: 1974-1983" in If Texas Were Chile edited by Philip E. Brock. San Francisco: Institute for Contemporary Studies Press, 1992.

Eichengreen, Barry, Andrew, Rose, and C. Wyplosz, 1995,'Exchange Market Mayhem: The Antecedents and Aftermath of Speculative Attacks" (Berkeley, California, University of California).

Ghosh, Saibal and Abhiman Das (2004) "Market Discipline in Indian Bank: Does the Data Tell a Story", EconPaper, Working Paper, .

Gurben, C. and William, Jahyeong Koo, and Robert R. Moore (1998), "When Does Financial Liberalization Make Banks Risky? An Empirical Examination of Argentina, Canada, and Mexico", Working Paper, Federal Reserve Bank of Dallas.

Gurben, C. and William, Jahyeong Koo, and Robert R. Moore (1999), "Financial Liberalization, Market Discipline and Bank Risk", Working Paper, Federal Reserve Bank of Dallas.

Gruben, William C., and Robert P. Macomb (2003) "Privatization, Competition, and Super Competition in the Mexican Commercial Banking System," Journal of Banking and Finance 27, 229-249. 
Gruben, William C., and Robert P. Macomb (1997) "Liberalization, Privatization, And Crash: Mexico's Banking System in the 1990s," Federal Reserve Bank of Dallas, Economic Review, (First Quarter).

Kaminsky, Graciela L. and Carmen M. Reinhart, the Twin Crises: The Causes of Banking and Balance-of-Payments Problems, "Federal Reserve System International Finance, Discussion Papers, No. 544, 1996.

Fischer, Klaus P. and Chenard, Martin (1997), "Financial Liberalization Causes Banking System Fragility" Available at SSRN: http://ssrn.com/abstract=25537 or DOI: $10.2139 /$ ssrn.25537

Lau, Lawrence. (1982). "On Identifying the Degree of Competitivieness from Industry Price and Output Data." Econometric Letters 10, 93-99.

McKinnon, Ronald I., and Huw Pill, 1996, "Credible Liberalization and International Capital Flows: The Over-borrowing Syndrome" In Financial Deregulation and Intergration in East Asia, edited by T. Ito and A. O. Krueger. Chicago: Chicago University Press.

Mondschean, S. Thomas and Timothy P. Opiela, 1998, "Bank Time Deposit Rates and Market Discipline in Poland: The Impact of State Ownership and Deposit Insurance Reform," Working paper series, WP-98-13, Federal Reserve Bank of Chicago.

Molyneux, Philip, D. Michael Lloyd-Williams, and John Thornton (1994) "Competitive Conditions in European Banking." Journal of Banking and Finance 18, 445-459.

Molyneux, Philip, John Thornton, and D. Michael Lloyd-Williams (1996).

"Competition and Market Contestability in Japanese Commercial Banking." Journal of Economics and Business 48, 33-45.

Panzer, John C., and James N. Rosse (1982) "Structure, Conduct and Comparative Statistics.” Bell Laboratories Economics Discussion Paper, Bell Laboratories.

Panzer, John C., and James N. Rosse (1987) “Testing for Monopoly's Equilibrium." Journal of Industrial Economics 35, 443-456.

Rosse, James N. and John C. Panzer (1977) "Chamberlin vs. Robinson: An Empirical Test for Monopoly Rents.” Bell Laboratories Economics Discussion Paper No. 90, Bell Laboratories. 
Shaffer, Sherrill (1982) "A Non-structural Test for Competition in Financial Merkets.” In Bank Structure and Competition. Conference Proceedings, Federal Reserve Bank of Chicago, pp. 225-241.

Shaffer, Sherrill (1993) "A Test of Competition in Canadian Banking." Journal of Money Credit and Banking, 25, 49-61

Shaffer, Sherrill (1994) "Evidence of Monopoly Power among Credit Card Banks." Federal Reserve Bank of Philadelphia Working Paper No. 94-16, 1994.

Shaffer, Sherrill (1997) “The Winner's Curse in Banking," The Federal Reserve Bank of Philadelphia, Working Paper No. 97-25.

McKinnon, Ronald I. and Huw Pill. ( 1996) "Credible Liberalizations and International Capital Flows: The Over-borrowing Syndrome.” in Financial Deregulation and Integration in East Asia, edited by Takatoshi Ito and Anne O. Kruger, Chicago: The University of Chicago Press.

Wyplosz, Charles (2001) "How Risky in Financial Liberalization in the Developing Countries?" Paper Presented at a Conference organized by the Research Program of the Group of 24 in Geneva on September 14-15, 2000. 


\section{Appendix A}

\section{Summary of Hypotheses and Expected Signs}

\begin{tabular}{|c|c|c|}
\hline Equation & Variable Description & Expected Signs \\
\hline $\begin{array}{l}\text { Dependent Variable: } \\
\text { Equation }(1): \\
\text { RTDEPGROW }\end{array}$ & $\begin{array}{l}\text { Growth Rate of Inflation } \\
\text { Adjusted Total Deposit }\end{array}$ & \\
\hline $\begin{array}{l}\text { ASSETQUALITY: } \\
\text { Alternatively use LLRG, } \\
\text { LLLP, LLRL, ILGL }\end{array}$ & $\begin{array}{l}\text { (i) Ratio of Loan Loss } \\
\text { Reserve to Gross Loan } \\
\text { (LLRG); (ii) Ratio of } \\
\text { Loan Loss Provision to } \\
\text { Net Internal Reserve } \\
\text { (LLLP); (iii) Loan Loss } \\
\text { Reserve to Impaired Loan } \\
\text { (LLRL); and (iv) } \\
\text { Impaired Loan to Gross } \\
\text { Loan (ILGL). }\end{array}$ & $\begin{array}{l}\text { If the coefficient is negative and } \\
\text { significant then we establish } \\
\text { depositor discipline at work. }\end{array}$ \\
\hline \multicolumn{3}{|l|}{$\begin{array}{l}\text { Equation (6) and (10): } \\
\text { Dependent Variable (6): Q } \\
\text { and Dependent Variable } \\
(10): \mathrm{P}\end{array}$} \\
\hline $\mathrm{P}$ & $\begin{array}{l}\text { Ratio of Interest Income } \\
\text { to Total Assets }\end{array}$ & \\
\hline Q & Total Assets & \\
\hline $\mathrm{Y}$ & GDP in Constant Dollars & \\
\hline $\mathrm{Z}$ & Deposit Rate & \\
\hline W1 & $\begin{array}{l}\text { Ratio of Interest Expense } \\
\text { to Total Liabilities }\end{array}$ & \\
\hline W2 & $\begin{array}{l}\text { Ratio of Employee } \\
\text { Expense to Total } \\
\text { Liabilities }\end{array}$ & \\
\hline $\mathrm{C}$ & $\begin{array}{l}\text { Ratio of Total } \\
\text { Expenditure to Total } \\
\text { Assets }\end{array}$ & \\
\hline $\mathrm{D}$ & $\begin{array}{l}\text { Year dummy is } 0 \text { if year } \\
\text { before } 1997 \text { and } 1 \text { if it is } \\
\text { after }\end{array}$ & \\
\hline $\begin{array}{l}\beta_{5} \text { and } \\
\lambda+\beta_{5}\end{array}$ & & $\begin{array}{l}\text { If we find that the value of } \beta_{5} \text { is } \\
\text { negative and large, that will } \\
\text { imply that banks significantly } \\
\text { increased the riskiness of its } \\
\text { behavior after liberalization or } \\
\text { privatization. }\end{array}$ \\
\hline
\end{tabular}




\begin{tabular}{|l|l|c|}
\hline Equation & Variable Description & Expected signs \\
\hline $\begin{array}{l}\text { Equation (11): Dependent } \\
\text { Variable }: \log \text { of P }\end{array}$ & $\begin{array}{l}\text { Ratio of Gross Interest } \\
\text { Revenue to Total Assets }\end{array}$ & \\
\hline W1 & $\begin{array}{l}\text { Ratio of Interest Expense } \\
\text { to Total Deposits and } \\
\text { Money Market Funding }\end{array}$ & \\
\hline W2 & $\begin{array}{l}\text { Ratio of Personnel } \\
\text { Expense to Total Assets }\end{array}$ & \\
\hline W3 & $\begin{array}{l}\text { Ratio of Other Operating } \\
\text { and Administrative } \\
\text { Expense to Total Assets }\end{array}$ & \\
\hline Y1 & $\begin{array}{l}\text { Ratio of Equity to Total } \\
\text { Assets }\end{array}$ & \\
\hline Y2 & $\begin{array}{l}\text { Ratio of Net Loans to } \\
\text { Total Assets }\end{array}$ & \\
\hline Y3 & Logarithm of Total Assets & \\
\hline $\begin{array}{l}\text { PR H-Statistics } \\
\text { H=sum of coefficients of } \\
\text { log of W1, W2 and W3 } \\
\text { variables }\end{array}$ & \multicolumn{1}{|c|}{$\mathrm{H}<0$} & Monopoly \\
\hline & $0<\mathrm{H}<1$ & Monolistic Competition \\
\hline
\end{tabular}

